\title{
NATO 70 - Öregkor vagy megújulás?
}

2019. április 4-én ünnepelte 70. születésnapját az Észak-atlanti Szerződés Szervezete. 70 év szép kor, különösen, ha katonai szövetségek léptékével mérjük. A 12 alapító által útjára indított, és immáron 29 tagúvá bővült szervezet történelmi távlatokban nézve is példátlanul sikeres életpályát mondhat magáénak. Globális szinten a NATO napjaink legerősebb politikai-katonai szövetsége, amelynek országai egyedülálló érték- és érdekközösséget alkotnak. Történelme során a NATO bebizonyította, hogy az észak-atlanti térség biztonsági architektúrájának sarokköveként képes a régió védelmének és stabilitásának szavatolására; a tagállamok közti belső kohézió fenntartására; valamint a külső szereplők irányából érkező potenciális fenyegetések katonai elrettentésére is.

Ám a számtalan pozitívum mellett a 70 év más szempontból is szimbolikus jelentőséggel bír. Jól érzékelteti ugyanis azt, hogy e hosszú időszak alatt számos generáció életében játszott kulcsszerepet a szövetség. A második világháború traumájából újraéledő, majd szinte egyből a hidegháborúba lépő társadalmak szempontjából a NATO szerepe megkérdőjelezhetetlen volt, hiszen az a mindennapjaikat érintő evidenciának számított. A bipoláris világrendszernek azonban csaknem 30 éve vége, azóta pedig - javarészt a NATO fennmaradásának, bővülésének és katonai garanciáinak köszönhetően - a lakosság egyre kisebb része mondhatja el magáról, hogy közvetlen tapasztalattal rendelkezne bármilyen katonai fenyegetésről. Sőt, lassan felnőtt vagy éppen felnő egy olyan nemzedék is, amelynek már a jugoszláv háborúk és 2001. szeptember 11-e is csak a különböző tudósításokból és beszámolókból lehetnek ismerősek. Mindez korántsem baj, ám jól szemlélteti azt a tendenciát, hogy lassan, de biztosan növekszik azok száma, akik nem tapasztalták, és ennélfogva nem feltétlenül érthetik a NATO szerepének fontosságát.

A szövetség - legyen az bármilyen jelentős is hazánk vagy a térség biztonságának fenntartása szempontjából - azonban csak annyira lehet erős és stabil, amennyire a társadalmaink elkötelezettek és hajlandók létezését támogatni. E támogatás fenntartása hosszú távon elképzelhetetlen a fiatalok megnyerése nélkül. A kérdés tehát adott: hogyan tudja egy kétségtelenül sikeres, ám kissé korosodó és néha az öregedés kezdeti jeleit mutató szervezet az új generációk felé fordulva is demonstrálni létjogosultságát? Hogyan győzhető meg a szövetség jelentőségéről egy olyan nemzedék, amelynek - logikus módon - már nem az atomháború, hanem egy potenciális klímakatasztrófa jelenti az egyik legnagyobb fenyegetést? A biztonság változó tartalmához kapcsolódó, nem hagyományos feladatokban történő szerepvállalás; az új típusú médiakörnyezetre támaszkodó, hatékony stratégiai kommunikáció; a közvetlen társadalmi problémákra reflektáló üzenetek mind elösegíthetik ezt. Ami persze nem azt jelenti, hogy a NATO-nak fel kellene adnia hagyományos feladatait. Sokkal inkább csak azt, hogy e tradicionális feladatok ellátása nem képzelhető el megfelelő fokú alkalmazkodás és átalakulás nélkül. A lecke fel van adva, de az már a szövetségen és annak tagjaink múlik, hogy a 70. születésnapot az öregkor vagy a megújulás követi majd. 